\title{
Auditing in Algeria within the Framework of Implementing Corporate Governance
}

\section{Benguetib Ali}

\author{
University of M'Sila, Third Cycle Doctorate student; Email: aali_Imd@hotmail.com
}

\section{Dr. Gasmi Said}

Assistant Professor, University of M'Sila; Email: Gasmi_sa@yahoo.fr

Doi:10.5901/ajis.2016.v5n2p21

\section{Abstract}

On the one hand, this study aims to investigate the connection between auditing and corporate governance, in a time when corruption and fraud are spreading all over Algeria, by portraying the key developments of auditing throughout different statutory texts and within the framework of implementing corporate governance. On the other hand, this study points to the importance of having audit committees in Algerian corporations due to their significance in realizing control over the roles of both internal and external auditors, as well as the board of directors, considering that they are one of the most important mechanisms of corporate governance. And thus, the quality of financial reporting accessible to financial statements' users can be enhanced.

Keywords: Auditing, corporate governance, audit committees

\section{Introduction}

Auditing is considered to be the backbone of any given corporation owing to its reflective characteristics of the economical activity therein. It plays a major role inside the big entities by providing safety and stability to their financial situations on the one hand, and on the other, it protects the rights of stakeholders. Auditing is also an economical and social function; it is a procedure required by law and organized by professional control authorities. The process of auditing is performed according to a set of Generally Accepted Auditing Standards (GAAS). Therefore, it must attend to the interests of the beneficiary parties by providing high proficiency and quality consulting and assuring services.

Companies can achieve the highest degree of transparency possible when having two main pillars: a consistent full disclosure system and quality financial reporting which will assist shareholders to enjoy their rights based on scientific grounds. Experience shows that disclosure along with quality financial reporting provided in financial statements both create a powerful tool to make sure that corporation management is acting the right way according to plans, it also protects the rights of investors and other concerned parties. Hence, a disclosure system which provides financial reporting released in the right time helps to bring capitals and maintain trust among investors and financial markets. Disclosure and quality financial reporting are essential in a sense that they increase the need of companies to finance via financial markets, stock exchange and bonds. Financial markets are usually supervised by professional or quasigovernmental authorities, this compels companies enrolled in these markets to comply with the procedures, laws and guidelines set forth by the profession. In order to enhance the trust of users in financial reporting provided in financial statements, data ought to have a major impact on the decisions made by users. It should also be equally beneficial to all and not to one category over another. Last but not least, it should be comparable which requires firmness in applying accounting policies. (Alanzi, A., M., H. (2014).

\section{Statement of the Problem}

Corporate governance system includes a set of mechanisms aiming to regulate the conduct of managers and minimize conflicts among involved parties in a way that attends to their interests, creates an indoor and outdoor stress-free positive work environment and stimulates the role of auditing process.

The main issue of this paper arises; to what extent does corporate governance contribute to activating the role of auditing process in Algerian corporations? 


\section{Hypotheses}

Three hypotheses can be suggested as follows:

- Hypothesis $N^{\circ} 1$ : Implementing governance in Algerian corporations would boost the quality of auditing in Algeria.

- Hypothesis $\mathrm{N}^{\circ}$ 2: Implementing corporate governance leads to enhancing the quality of financial reporting.

- Hypothesis $N^{\circ} 3$ : The occurrence of financial crises and collapses as well as the separation between property and management compels Algerian corporations to implement corporate governance along with the function of auditing.

\section{Significance of the Paper}

The significance of this paper lies in that corporate governance contributes in achieving the goals set by the function of auditing, especially with the rising need to develop it in Algeria, thanks to the high quality services it provides, which in return, enhances the quality and proficiency of data provided for financial statements' users.

\subsection{Purposes of the paper}

The main purpose of this essay consists in finding out the arrangement of the profession of auditing in Algeria through implementing the framework of corporate governance, this latter which helps to protect auditing from phenomena like cheating, corruption and fraud, especially in the light of the recent events that took place in the country namely the case of Khalifa and the case of the East-West high way.

\subsection{Approach of the paper:}

This essay uses a descriptive analytical approach when talking about the theoretical framework of auditing, and a historical approach when talking about the chronological development and different phases of the profession of auditing in Algeria.

\subsection{Previous studies:}

Previous studies conducted in this field briefly include:

- (Abdessamad, O., A. (2013). Al Bahith magazine, Ouargla)

The author of this work shed the light on the strengths and weaknesses of the frameworks of governance in both Algeria and Egypt by comparing them to the principles of the Organization for Economic Co-operation and Development. This study came to the conclusion that it is necessary to recreate the framework of governance in Algeria and conform it to the principles of the organization.

- (Belberkani, O., Kh. (2014). Kounouz Al Hikma publishing company, Algeria)

The main conclusion that this work came to is that corporate governance system can be judged based on its ability to deal with and solve different conflicts resulting from parties refusing alliance. An active system is one that should avoid destroying value for parties involved. Moreover, it should be capable of setting the terms allowing it to revive the ability of the corporation to grow at minimal costs.

- Inuwa, Fodio Musa, Ibikunle, Jide and Oba, Victor Chiedu (2013). Corporate governance mechanisms and reported earnings quality in listed Nigerian insurance firms. International Journal of Finance and Accounting 2.5, 279-286.

This study aims to investigate the dynamism of good corporate governance rules for the insurance industry in Nigeria which have the ability to reduce earnings management, thus, enhancing the process of making financial statements as well as enhancing quality.

- Al Attar, Mohammad Khalid (2014). The impact of the auditor to achieve governance from the perspective of investors in Amman stock exchange market. Social Sciences GB14 Mumbai Conference, Vol. 19.

This study points to the connection between corporate governance and the credibility of the gap (audit expectation gap) by means of financial mediators acting as representatives for shareholders in Oman's stock market. Furthermore, the paper examines the level of commitment of auditors to implement the International 
Standards on Auditing (ISA) as well as the International Standards on Quality Control (ISQC) as independent variables that could affect corporate governance.

What sets our study apart from the above mentioned ones is the fact that it focuses on the role of corporate governance in achieving high quality audit in Algeria, by implementing the most important standards of corporate governance, hence, reaching the goal of the process of auditing namely when it comes to producing quality financial reporting that meets the needs of its users.

\section{Theoretical Framework of the Study}

\subsection{Defining audit:}

Audit consists mainly in checking financial information and data by an independent neutral person of any corporation regardless of its purpose, size or legal form. The American Accounting Association (AAA) defined auditing as "organizing procedures made to get evidence about economic balances and events by objectively assessing them for determining the connection level between balances and a particular scale in order to convey results to users." (Attamimi, H. (2006).

\subsubsection{The profession of auditing:}

It is the process of legal accounting including its two branches accounting and auditing. It involves a series of services related philosophically, practically and logically provided by professional members to corporations and individuals. These services include consulting services, accounting services and tax services. (Almekhadema, A., A. and Rashid, H. (2007).

\subsection{Corporate Governance:}

The term "Hawkamat" in Arabic is originally derived from the English term "governance". The Arabic term was created by the Academy of Arabic Language in an attempt to arabize the word which has other meanings such as good governance. Thus, the term "corporate governance" is translated into Arabic by the term "Hawkamat el Charikat" (Ibrahim, H., Kh. (2014).

Corporate governance as a concept aims to regulate business affiliations firstly among the board of directors in different companies, branch CEO's and audit committees assigned in the board of directors, and secondly, among shareholders, project stakeholders, accountants and companies.

\subsubsection{Defining corporate governance:}

Corporate governance is a set of rules, regulations and procedures combined to achieve the best balance between the interests of company CEO's, shareholders and other concerned parties by implementing different means of control. (Alanzi, previous reference)

Corporate governance is also a set of mechanisms used to protect shareholders and guarantee them collecting the right earnings of the investment. Therefore, financial statements play a crucial role in a way that they are the basic documents shareholders look at for guaranteed quality financial data. Companies are required to ratify accounting records by accountants, and the same goes for any individual working for governance. The compensations matter is also considered to be very necessary. Le Maux, Julien (2014).

\subsubsection{Principles of corporate governance:}

The principles of corporate governance issuing from the Organization for Economic Co-operation and Development (OECD) intend to present the most eminent and exemplary standards of the profession. These principles are organized into six chapters as follows: 
Table 1: Principles of corporate governance

\begin{tabular}{|c|c|c|}
\hline & $\begin{array}{l}\text { To guarantee having an efficient } \\
\text { corporate governance framework }\end{array}$ & $\begin{array}{l}\text { - Influencing in terms of overall economical } \\
\text { performance; } \\
\text { - Regulatory and legal requirements within a legislative } \\
\text { jurisdiction; } \\
\text { - Dividing responsibilities among involved parties within } \\
\text { a clear legislative jurisdiction and at the service of public } \\
\text { interest; } \\
\text { - Different parties have the integrity, power and } \\
\text { resources to perform their duties. }\end{array}$ \\
\hline \multirow[t]{5}{*}{$\begin{array}{l}\text { Organization for Economic Co- } \\
\text { operation and Development }\end{array}$} & $\begin{array}{l}\text { To protect the rights of } \\
\text { shareholders. }\end{array}$ & $\begin{array}{l}\text { - Availability of the basic rights of shareholders; } \\
\text { - The right to be informed about decisions; } \\
\text { - The right to participate in votes; } \\
\text { - Facilitating active participation; } \\
\text { - Casting votes personally or via absentee voting; } \\
\text { - Disclosing structures and arrangements; } \\
\text { - Facilitating ownership. }\end{array}$ \\
\hline & Equal treatment of shareholders. & $\begin{array}{l}\text { - Equal treatment for shareholders (of the same share } \\
\text { class); } \\
\text { - Preventing exchange among internal auditors as well } \\
\text { as preventing formal personal exchange; } \\
\text { - Disclosing operations. }\end{array}$ \\
\hline & To respect the role of stakeholders. & $\begin{array}{l}\text { - Interests according to law and agreements; } \\
\text { - Compensation for right violation; } \\
\text { - Developing participation mechanisms; } \\
\text { - Providing information in the right time; } \\
\text { - Attending to the profession's practices; } \\
\text { - A framework for insolvency and another for creditors. }\end{array}$ \\
\hline & Disclosure and transparency & $\begin{array}{l}\text { - Disclosing policies; } \\
\text { - Quality levels of accounting; } \\
\text { - External control; } \\
\text { - Audit's liability to accountability; } \\
\text { - Opportunity and timing; } \\
\text { - Efficient approach of governance framework. }\end{array}$ \\
\hline & $\begin{array}{l}\text { Responsibilities of the board of } \\
\text { directors }\end{array}$ & $\begin{array}{l}\text { - Working by full information; } \\
\text { - Equal treatment for shareholders; } \\
\text { - Implementing ethical standards; } \\
\text { - Disclosing policies; } \\
\text { - Independent objective judgment in the right time to } \\
\text { provide information. }\end{array}$ \\
\hline
\end{tabular}

Source: Kadi, Hoceine and Nadah, Kinen (2010)

\subsubsection{The importance of implementing corporate governance:}

The importance of implementing corporate governance can be summed up as follows: (Abdelbaz, M., M. (2012).

1. Boosting reliability by having financial reporting control go through independent authorities and by confirming the review process by means of control bodies within the governance;

2. Working on minimizing and preventing manipulation and distortion of financial statements through a set of mechanisms applicable by corporate governance on the economic unit;

3. Diminishing the phenomenon of asymmetric information;

4. Working on minimizing and preventing the phenomenon of earnings management which constitutes the most important part for financial statements' users.

It is worth mentioning that the importance corporate governance attaches to the principle of disclosure and transparency is due to several goals such as:

- Providing financial statements up to correct accounting processing and standards fairly showing the financial 
status of the company, the results its business came to achieve, and its cash flow, as well as providing sufficient disclosure and transparency through financial and non financial data enrolled therein, so as to cater the needs of financial statements' users including investors, banks and financial analysts;

- Describing different elements recognized in financial statements and providing norms for interpreting and analyzing those elements other than those mentioned in financial statements, and working on further recognition through complementary explanations of each of the elements of financial statements;

- $\quad$ Finding alternative recognition norms for non financial information and elements which are not recognized in financial statements;

- If implemented correctly according to governance, the principle of disclosure and transparency makes sure that when describing recognized elements, economic units are working by accounting standards.

\subsection{Audit committee:}

Audit committee is a partial committee consisting of non executive members of the board of directors. It is founded in order to follow the activities of internal control, internal auditors, external auditor and to enhance the quality level of financial statements. Audit committee is characterized by the following features: (Samra, Y., M. (2014).

- It originates from the board of directors;

- It is formed of non executive members of the board of directors;

- It has members counting from 3 up to 9;

- It exercises a number of jurisdictions set for it by organizing professional authorities, and it is intrinsically related to enhancing the quality level of financial statements as well as increasing the independence of internal and external auditors;

- It includes at least one member having accounting and financial expertise.

Keung C. R. Ashok and T. Daneil's study points out to the part audit committees play in activating corporate governance. Their study focuses also on the dynamic role and the active impact audit committees have on assisting management in solving different problems it encounters, provided that audit committees' members are surrounded by a protective shield of neutrality and independence. Furthermore, audit committees help in facing different risks a corporation might experience. (Keung, C., Ashok, R. and Daneil Sarbanes-Oxley, T. (2007)

\subsubsection{The importance of the assessment process by audit committees:}

Members of audit committees are considered to be in a powerful position when controlling financial statements system, precisely, when controlling accounting fraud. Most audit committees who did not detect accounting fraud were likely misled by the CEO or the financial manager. Therefore, audit committees must ask management and employees for they could be under pressure to magnify earnings incorrectly. Audit committees are also required to make inquires with internal and external auditors. It is crucial to carefully evaluate the auditors' responses to those inquiries because the auditor might not provide full statements for three reasons: (Abulhaidjaa, M. and Alhayek, A. (2013).

- Management can persuade the auditors to be involved in the fraud operation;

- Management can force the auditor to hide certain information from the audit committee;

- The auditor cannot detect fraud sometimes. That is why audit committees must not take the statements of the external auditor for granted. 


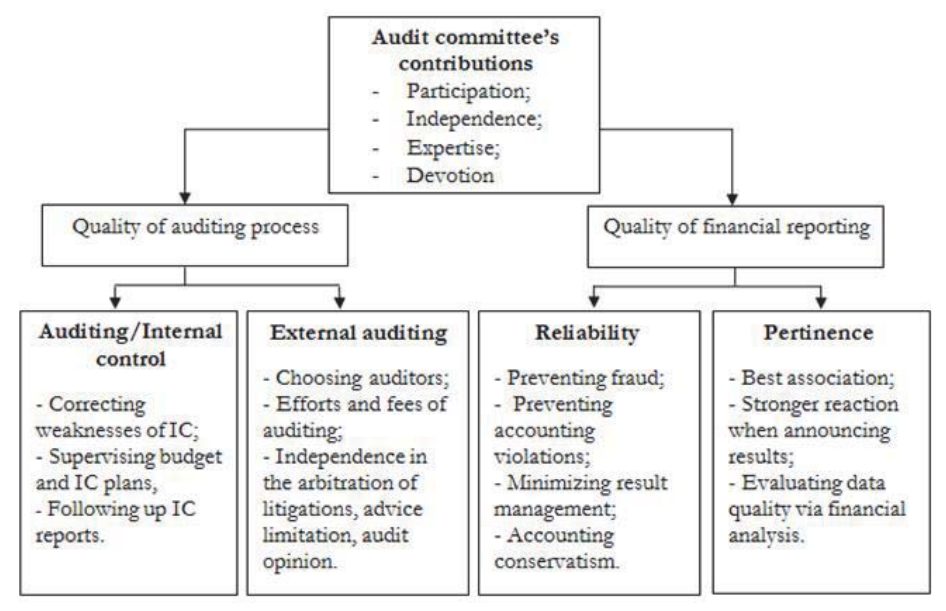

Figure $\mathrm{N}^{\circ}$ 01: Analytical framework of audit committee's contributions

Source: Piot, Charles and Kermiche, Lamya (2009). À quoi servent les comités d'audit? Un regard sur la recherche empirique, Livre-Revue-NumSpecial - Comptabilité - Contrôle - Audit, indb 11, 13.

\section{Practical Part: Auditing and Corporate Governance in Algeria}

Auditing as a profession went through several changes due to certain circumstances. It also encountered many problems in Algeria on various levels such as regulations and management just to name a few.

1. Auditing in Algeria: Auditing was implemented in Algeria as follows:

$>$ Prior to independence: Auditing was governed by French colonialism's regulations.

$>$ After independence: French colonialism, as in many other fields, left a big gap as far as auditing profession is concerned. This latter faced several regulation and management problems. The phases auditing underwent can be summarized as follows:

\subsection{First phase: From 1969 to 1980}

Performing accounts auditing as a profession in economic public corporations was first regulated in Algeria in 1969 in compliance with the order 69-107 dated 31st December, 1969 pertaining to finance act of 1970 of which the article 39 stipulates that the Secretary of State in charge of finances and planning is ought to designate accountants in national companies, public industrial and commercial corporations and in companies where the state holds a percentage of the social capital in order to insure the regularity and reliability of the accounts as well as to analyze the situation of assets and liabilities. (Seddiki, M. (2004).

- $\quad$ Then was issued decree 70-173 dated $16^{\text {th }}$ November, 1970 which sets duties and tasks of book keepers in public and semi-public corporations. The text of auditing (book keeping) serves as a permanent controller for management in these corporations.

- Order 71-82 dated 29th December, 1971 pertaining to the regulation of the profession of accounting and financial expert. It is noted in this order that it is concerned with accountants and expert accountants. As for book keeping, it was entrusted to the Inspectorate General of Finances (called Inspection Générale des Finances in Algeria) of the Ministry of Finances.

\subsection{Second phase: From 1980 to 1992}

After reorganizing national economy and structuring public economic corporations which resulted in an increase of the number of public corporations, a complexity of management patterns, an absence of data generation control frameworks and weakness in managing accounting system, the Algerian legislator was forced to decree control mechanisms that would restrict the different kinds of disorganizations caused by the old ways. Consequently, were issued: (Ghouali, M., E. 
- Act 80-05 dated 30 $30^{\text {th }}$, October 1980 pertaining to the practice of the function of control by the Court of Audit (Cour des Comptes) in order to establish efficient control mechanisms for national corporations by making restructures and by limiting embezzlement and bad management.

- Act 91-08 dated 27 , April 1991 pertaining to the profession of accounting expert, book keeper and certified accountant. This act is considered to be a decisive point in the history of auditing profession organization in Algeria. Three organizations were gathered into one independent authority called the national union for accounting experts, book keepers and certified accountants.

Thus, the condition of independence was fulfilled by assigning these people without turning to the guardian ministry.

N.B. Act 88-01 pertaining to the directive law for public economic corporations was issued to break the restrains forced upon them, help them gain financial independence, make them conform to the rules of commercial law and be exposed to bankruptcy and liquidation. This necessitated accounts auditing and validation by experts such as book keepers and certified accountants. As a result, was issued act 91-08 regulating the profession of accounting experts and book keepers.

- Executive decree 92-20 dated $13^{\text {th }}$, January 1992 pertaining to the creation of the national union for accounting experts, book keepers and certified accountants.

\subsection{Third phase: From 1994 to 2010}

- Decree dated 07th, November 1994 pertaining to the pay scale of book keepers amended in 2006.

- Executive decree 96-136 dated 15th, April 1996 pertaining to the work ethics of auditing and accounting.

- Executive decree 96-136 dated 25th , September 1996 pertaining to the creation of the National Council of Accounting (Conseil National de la Comptabilité) as a consulting authority in the Ministry of Finances. It is invested in research, development and standardization of the profession of accounting.

- Executive decree 96-431 dated 30 3 , November 1996 pertaining to the methods of assigning book keepers in public industrial and commercial corporations, research and development centers, social security agencies, public commercial offices and dependent public corporations.

- Executive decree 97-458 dated 015t, December 1997 amending and supplementing executive decree 92-20 (attaching a state's representative from the Ministry of Finances)

- Decision dated 28 $8^{\text {th }}$, March 1998 determining methods of publishing rating scales of degrees and diplomas entitling the right to practice the professions of accounting expert, book keeper and certified accountant.

- Decision dated $24^{\text {th }}$, March 1999 setting approval of diplomas and professional expertise conditions for practicing the profession.

- Executive decree 01-421 dated 20th, December 2001 amending and supplementing executive decree 92-20 which establishes the structure of the national union for accounting experts, book keepers and certified accountants and sets its jurisdictions and work regulations.

- Act 10-01 dated 29th, June 2010 pertaining to the professions of accounting expert, book keeper and certified accountant.

The following table (table 2) shows the most important laws like so:

\section{Table 2}

\begin{tabular}{|l|c|c|c|c|c|c|c|c|c|c|c|c|c|c|}
\hline & 1969 & 1970 & 1971 & 1980 & 1991 & 1992 & 1994 & 1996 & 1997 & 1998 & 1999 & 2001 & 2010 & Total \\
\hline Act & & & & 1 & 1 & & & & & & & & 1 & 3 \\
\hline Order & 1 & & 1 & & & & & & & & & & & 2 \\
\hline Decree & & 1 & & & & 1 & 1 & 3 & 1 & & & 1 & & 8 \\
\hline Decision & & & & & & & & & & 1 & 1 & & & 2 \\
\hline
\end{tabular}

Source: We made this table ourselves on the basis of different laws issued in Algeria.

Based on this table, where we show the progress of the profession of auditing in Algeria since the independence, we notice that the total of acts reached 3 , and the total of orders and decisions was 2 for each, whereas executive decrees reached a total of 8 . 
The last amendment made on the organizational laws of auditing was the amendment 10-01 concerned with the payment methods of auditor's fees which relies on the code of auctions instead of following the scale that once sat the auditor's fees based on several factors such as the corporation's turnover and the time taken to perform tasks. As for the auditor's contract term in Algeria, it spans over a period of three years renewable just once. If renewed, the auditor can contract with the same corporation but after three years, to maintain the principle of auditors' exchange. As far as auditing national standards are concerned, the organization of this profession is confined to a number of organizational laws published only in official newspapers. There are no detailed national standards for external auditing in Algeria. (Ibn Said, M. and Lechlèche, A. (2015).

\subsection{Auditors according to Algerian legislation:}

Various notions of auditor's independence can be found in the profession's literature. This came along with a progress of the auditor's responsibilities and services he/she provides, as well as an evolution in terms of society's professional outlook. This concept evolved to embrace control standards on the performance quality of accounting offices and to compel them to establish policies and procedures to carry out the independence rule mentioned in the profession's work ethics. These policies and procedures may include: (Youness, Z. (2014).

- Controlling to what extent accounting and auditing offices are abided by the policies and procedures of independence;

- $\quad$ Assuring the independence of the accounting office when performing the task of control;

- Requesting all employees in the accounting office to abide by the independence rule provisions issued by professional communities.

\subsection{Corporate governance in Algeria:}

Algeria aspired to establish an effective framework for corporate governance through some legislations and initiatives. This came as a result of the growing awareness to implement governance by stakeholders within these corporations, and by countries to diminish the phenomenon of financial fraud that occurred lately.

6.6 Presentation of the content of the charter of good governance of the Algerian corporation (Abdessamad, O., A. (2013).

Algerian business associations and unions made an initiative to find out ways of encouraging good governance within the business community in order to attract direct foreign investment. To conduct this operation, stakeholders in both public and private sectors founded in 2007 a work group for corporate governance operating side by side with the Global Corporate Governance Forum (GCGF) and the International Finance Corporation (IFC) to set a framework for corporate governance in Algeria. And on the $11^{\text {th }}$ of March 2009, a national conference was held where CARE Association and the National Corporate Governance Committee in Algeria announced the issue of the Algerian corporate governance guidebook, which was made by the help of the Global Corporate Governance Forum (GCGF) and the International Finance Corporation (IFC). The charter comprises two sections and annexes as follows:

- The first section explains the motives behind good corporate governance becoming necessary in Algeria. It also finds links to difficulties and problems Algerian corporations face, in particular small, medium and private corporations;

- The second section deals with the main standards good corporate governance should work by. On the one hand, it portrays connections between the organizational authorities of the corporation (General Assembly, Board of Directors and the Executive Directorate), and on the other, connections between the corporation and other partners such as banks, financial institutions, suppliers... etc. This section discusses also the quality of data publication and the means of property transfer;

- At the end of this charter, can be found annexes collecting a number of tools and practical advice corporations could go back to and make use of to respond to a certain precise concern, for instance, a referential practice list, self assessment of corporations' management, a multi-sided (panoramic) vision for Algerian corporations abiding by commercial law, conflict of interest within the corporation. 


\subsubsection{Purpose of the charter:}

The subject of this charter aims to place at the disposal of partially or entirely private Algerian corporations a practical simplified tool allowing the comprehension of the main principles of good corporate governance so that to start aspiring to apply these principles in reality. Therefore, the point of implementing the principles of this charter is to give the corporation tools to liberate its management by providing utmost security by means of defining the rights and the obligations of acting parties inside the corporation, sharing prerogatives and responsibilities arising from that and guaranteeing continuity and competitiveness within the corporation. This charter comes within the context of laws and regulatory texts in force. That is why it consents to them without pretending to be perfect, especially that texts in this field are abundant. It does not represent a comprehensive set of legal texts corpora; it rather is a referential document and an important source at the disposal of corporations. (Menad, A. (2014).

\subsubsection{Data quality and disclosure in the Algerian governance charter}

The Algerian charter stipulates the publication and disclosure of the corporation's annual financial situation according to the highest accepted international standards. As for corporations contributing in stock markets, they are required to publish their financial situation every trimester, along with all other information having a financial impact on the corporation's assessment. Thus, the charter recommended corporations to produce, in the right time, correct and full financial statements that could be requested by financial partners. (Saghor, M. (2013).

\subsection{The importance of having audit committees in Algerian corporations}

In spite of the intervention of the Algerian legislator to set regulations for protecting and assuring the independence of auditors, yet considering the progress made in the field of auditing, it could be said that Algeria has not yet reached the desired level, and that these legislations are not enough, especially when talking about the ethical standards compared to how it goes in the field in other parts of the world. This is mainly due to what happened over the past two decades namely after the stumbling and failing of stock-joint companies and because of an increase in accounting and financial violations to an extent that decreased the trust placed in financial statements, in addition to confirmed involvement of some accountants in what these companies were accused of; violations and breaches of independence rules. These violations exposed a huge information gap between internal and external parties of the company despite the progress level these countries achieved in the field of auditing and the quality of the standards they use. From this, arose the need to develop systems of assigning external auditors in a serious attempt to regain the trust of financial statements' users in the credibility and reliability of these reports. (Youness, Z. (2014).

\section{Conclusion:}

Based on all what has been said above, it is concluded that corporate governance enabled the profession of auditing to perform different assigned tasks in a better and easier way; it provided various mechanisms and tools which not only facilitated the operation of auditing, but also enabled it to better carry out different tasks. This was possible thanks to the many qualities gained of implementing corporate governance. Auditing in Algeria faces several challenges in terms of adapting to the international system. Hence, with corporate governance, Algeria as in the case of other countries, started to implement governance rules by executing some anti-corruption laws and other rules Yet, it still has a long way to go to firmly handle such phenomena due to the plotting of some parties on the one hand, and on the other, the lack of experience of those in charge of such operations.

The following results were concluded like so:

- The rising need for corporate governance in Algeria especially after granting independence to economical institutions;

- Auditing and corporate governance are intrinsically related which helps to eradicate the phenomenon of corruption;

- Corporate governance rules help to improve the quality of financial reporting provided for financial statements' users;

- A progress in terms of audit committees' proficiency, auditor's independence and executing international auditing standards; 
- An attempt to develop a framework for corporate governance in Algeria and adapt it to the international standards to avoid the phenomena of corruption and fraud;

- An attempt to formulate organizational laws which would compel Algerian corporations to have audit committees within their bodies thanks to the active role they play on control.

- Trying to learn from the experience of other countries in the field of corporate governance and audit committees, particularly the principles of the Organization for Economic Co-operation and Development (OECD).

\section{References}

(Alanzi, A., M., H. (2014). Alkadissia magazine for economic and administrative sciences)

(Attamimi, H. (2006). Wael publishing company)

(Almekhadema, A., A. and Rashid, H. (2007). Business administration magazine, Jordan)

(Ibrahim, H., Kh. (2014). Comprehensive economic sciences magazine, Baghdad)

Le Maux, Julien (2014). Effort d'audit et gouvernance: Le rôle des honoraires d'audit. Revue Recherches en Sciences de GestionManagement Sciences-Ciencias de Gestión, 102, 155.

(Abdelbaz, M., M. (2012). Scientific magazine, Suez Canal University)

(Samra, Y., M. (2014). Arabic magazine for administrative sciences, Kuwait)

Keung, C., Ashok, R. and Daneil Sarbanes-Oxley, T. (2007) Are audit committees up to the task? Managerial Auditing, Bradfold, Vol. 22 , Iss. 3, 225- 270 .

(Abulhaidjaa, M. and Alhayek, A. (2013). The Economic magazine, University of Aden)

(Seddiki, M. (2004). A dissertation submitted in partial fulfillment of the requirements for the Doctor's Degree, University of Algiers)

(Ghouali, M., E. (2004). A dissertation submitted in partial fulfillment of the requirements for the Doctor's Degree in economic sciences, University of Algiers)

(Ibn Said, M. and Lechlèche, A. (2015). Comprehensive economic sciences magazine, Baghdad)

(Youness, Z. (2014). Rouaa magazine, El Oued University)

(Abdessamad, O., A. (2013). Al Bahith magazine, Ouargla)

(Menad, A. (2014). A dissertation submitted in partial fulfillment of the requirements for the Doctor's Degree in development economics, University of Abou Bekr Belkaid)

(Saghor, M. (2013). Economy and human development magazine, University of Blida Saad Dahlab)

(Youness, Z. (2014). Rouaa magazine, El Oued University)

Kadi, H. and Nadah, K. (2010). Economical and legal sciences magazine, Damascus University

Piot, Charles et Kermiche, Lamya (2009). À quoi servent les comités d'audit? Un regard sur la recherche empirique. Livre-RevueNumSpecial-Comptabilité-Contrôle- Audit, 11.

Musa, Fodio Inuwa, Ibikunle, Jide and Oba, Victor Chiedu (2013). Corporate governance mechanisms and reported earnings quality in listed Nigerian insurance firms. International Journal of Finance and Accounting 2.5, 279-286.

Al Attar, Mohammad Khalid (2014). The Impact of the Auditor to Achieve Governance from the perspective of investors in Amman Stock Exchange Market. Social Sciences GB14 Mumbai Conference, Vol. 19. 